\title{
Examining the Effects of Leadership, Market Orientation and Leader Member Exchange (LMX) on Organisational Performance
}

\author{
Lo May-Chiun', Abang Azlan Mohamad ${ }^{2}$, T Ramayah ${ }^{3}$, Wang Yin Chai ${ }^{4}$ \\ 1, 2, ${ }^{4}$ Universiti Malaysia Sarawak \\ 94300 Kota Samarahan, Sarawak, Malaysia \\ E-mail.mclo@rimc.unimas.my,maazlan@feb.unimas.my \\ ${ }^{3}$ Universiti Sains Malaysia, \\ 11800 Gelugor, Pulau Pinang, Malaysia \\ E-mail.ramayah@usm.my \\ cross $^{\text {ref }} \underline{\text { http://dx.doi.org/10.5755/j01.ee.26.4.7656 }}$
}

Based on the theory of customer value, comprehending the needs of customers and creating value for them is crucial for organisations to be competitive in the marketplace. Although there is an upward trend in the study of customer value, it is not known if the impact of leadership and market orientation on performance was researched in any studies. In this study, the concept of market orientation is comprised of three-dimensional constructs, while leadership consists of two-dimensional constructs. This study endeavours to investigate the constructs of market orientation, leadership and organisational performance in a single framework. To do so, a total of 184 financial services companies in Malaysia took part in this research. The analysis highlights that organisational performance was impacted by various components of market orientation. This paper further discusses the findings' implications, limitation of the study and future research directions.

Keywords: Leaders, Market Orientation, LMX, Performance, Multinational Companies, Malaysia.

\section{Introduction}

In the present day, the majority of organisations are increasing efforts to stay competitive in order to achieve their vision and mission. One of the ways for organisations to realise their target and purpose is by cutting costs (Wichramasinghe et al., 2008). Apart from achieving their stated mission and vision, an organisation has to fulfil its obligation to return investments made by owners by obtaining superior performance. It is vital that an organisation employs the right strategies in its quest to achieve their goals, objectives and the desired performance to appease the organisation's stakeholders. In identifying the right strategies, one of the most common tactics engaged by organisations is market orientation, whereby an organisation attempts to identify and satisfy the needs of customers ahead of its competitors. With all of these in place, an effective leader is needed to guide and drive the organisation towards superior organisational performance.

The subject of leadership is regarded as an essential element in the study of organisations as it is regarded to be the foremost important ingredient in the success of an organisation. The performance of an organisation hinges on its leaders as an organisation sets out its mission and vision and determines its existence in the market (Zaccaro \& Klimoski, 2001). Creating and delivering value are vital components of the competitiveness and the marketability of an organisation (Berghman et al., 2006). As a result, organisations that are not innovative enough are likely to struggle in the market (Lonial et al., 2008).

The study of leadership principally focuses on transformational and transactional styles, both of which are regarded as novel approaches (Kuada, 2010). (Schneider \&
George, 2011) suggest that leaders who practice a transformational style have the capability to motivate and influence subordinates by inspiring them (Avolio et al., 2004; Dvir et al., 2002). It is a leadership style that promotes mutual cognizance among members of an organisation that elevates them to achieve shared objectives. Moreover, leaders who practice a transactional style of leadership emphasise task oriented duties, such as job standards and the objectives of jobs (Burns, 1978; Jogulu, 2010). Transactional leadership focuses on highlighting interests of individual leaders and their subordinates in accomplishing predetermined agreements of both parties by evaluating and observing their outcomes (Bass \& Avolio, 2000). Both leadership styles are not considered contradictory as leaders can practice both styles (Bass, 1985). (Gardner \& Stough, 2002) suggest that transactional leaders are less effective than transformational leaders because the motivational dimension of transformational leadership was found to surpass the leadership models of the transactional leadership style (Bass, 1985; 1997). Arham (2014) suggested that in order for the organisation to obtain support from employees in the desired objectives, it is crucial for leaders to inspire employees to learn and grow, to motivate them in attaining higher targets, to provide emotional support and guide them, to understand their needs and develop their skills and enhance their talent (Gillespie \& Mann, 2004). Therefore, this study is timely as past research (e.g. Bass, 1985; Tarabishy et al., 2005) underline that good leaders allow organisations to obtain superior performance, enhance employees' satisfaction and motivate employees (Papalexandris \& Galanaki, 2009).

Altuntas et al., (2013) contend that the study of market orientation is prevalent in the literature of marketing (Smirnova et al., 2011). The majority of these studies 